\title{
Study of the Association Between Diabetes and Helicobacter Pylori Infection in a Tunisian Population
}

\author{
Chaima Jemai, Rim Rachdi, Sonia Bellamine, Lamia Bouallegue, and Faika Ben Mami
}

\begin{abstract}
Introduction: The association between diabetes and Helicobacter Pylori (H. Pylori) infection remains controversial in the literature.

The aim of our study was to search an association between diabetes and $\mathrm{H}$. Pylori infection.

Methods: This is a case-control study carried out in 2017 over 3 months (September-October-November), collecting 120 patients with dyspepsia, matched for age and gender into two groups: a group of 77 patients with diabetes, and a group of control cases made of $\mathbf{4 3}$ non-diabetics. Diabetes was defined according to the American Diabetes Association (ADA) of 2017. Clinical, biological, endoscopic and anatomopathological data were collected from medical records.

Results: The average age of the patients was $50 \pm 2,1$ year. The sex ratio was 0.51 . $34.2 \%(n=41)$ patients were male. Diabetes was type 2 in the majority of cases $(88.31 \%)$ and type 1 in $11.68 \%$ only. $H$. Pylori infection was more prevalent in diabetics $(\mathbf{1 9 . 4 8 \%}, \mathbf{1 1 . 6 3 \%}, \mathrm{p}=\mathbf{0 . 2 7})$. H. Pylori infection was more prevalent in type 1 diabetics $(44.44 \%, 16.18 \%, p=0.04)$. The frequency of upper endoscopic lesions in diabetics and controls was $70.13 \%$ and $74.42 \%$, respectively. Chronic gastritis, gastric atrophy, and intestinal metaplasia were found in $61 \%, 3.9 \%$ and $2.6 \%$ of the cases in the group of diabetics and $62.79 \%, 6.98 \%$ and $4.65 \%$ respectively in the control group ( $\mathrm{p}=$ not significant $(\mathrm{NS}))$.

Conclusion: Our study shows the absence of a significant association between diabetes and $H$. Pylori infection, as well as the absence of endoscopic and histological specificities of this infection in patients with diabetes.
\end{abstract}

Index Terms - Diabetes, Helicobacter Pylori, infection.

\section{INTRODUCTION}

Helicobacter pylori (H. pylori) is a gram-negative spiral bacteria that colonize the stomach. $\mathrm{H}$. pylori infection is a global health problem affecting approximately $50 \%$ of the world's population [1]. It is characterized by inflammation of the gastric mucosa and a humoral and cellular immune response directed against the bacteria.

$\mathrm{H}$. pylori is the main agent responsible for chronic gastritis and its evolution over time to ulcer disease, gastric atrophy, and adenocarcinoma or mucosa associated lymphoid tissue (MALT) lymphoma [2], [3].

Published on August 30, 2020.

Chaima Jemai, National Institute of Nutrition and Food Technologies, Tunisia.

(corresponding e-mail: jemaichaima87@yahoo.fr)

Rim Rachdi, National Institute of Nutrition and Food Technologies, Tunisia.

Sonia Bellamine, National Institute of Nutrition and Food Technologies, Tunisia.

Lamia Bouallegue, National Institute of Nutrition and Food Technologies, Tunisia.

Faika Ben Mami, National Institute of Nutrition and Food Technologies, Tunisia.
The association between diabetes and H. pylori infection has been reported in the literature and is currently a subject of controversy. Weakened immune systems and delayed gastric emptying are among the pathophysiological mechanisms suggested explaining the proliferation of the bacteria in the upper gastrointestinal tract and the high prevalence of H. Pylori infection in diabetics [4]-[6].

The aim of our study was to describe the upper endoscopic and histological lesions in dyspeptic diabetics, to determine the prevalence of $\mathrm{H}$. Pylori infection and to seek an association between this infection and diabetes.

\section{METHODS}

\section{A. Type and location of the study}

This is a case-control study carried out in 2017 over 3 months (September-October-November), at department C of Diabetology of the National Institute of Nutrition and Food Technologies in Tunis, in collaboration with the Gastroenterology department of the same institution.

\section{B. Definitions}

The diagnosis of diabetes was made by referring to the recommendations of the American Diabetes Association (ADA) of 2017.

The diagnosis of an infection with H. Pylori was retained by the histological examination of biopsies made with oesogastro-duodenal fibroscopy.

\section{Recruitment of the population of the study}

We included all patients aged over 18 years, consulting for dyspeptic disorders and / or epigastralgia, who consented to participate in our study. We did not include patients with cancer and pregnant or lactating women.

A total of 120 dyspepsia patients were collected in our study. They were matched for age and gender into two groups: a group of 77 diabetics and a group of control cases of 43 non-diabetic patients.

All of the patients underwent oesogastroduodenal fibroscopy. Biopsies were performed in the presence of gastric or duodenal lesions.

We evaluated the socio-demographic characteristics of the patients, the characteristics of diabetes, the associated comorbidities, the digestive symptomatology, the results of the oesogastroduodenal fibroscopy and the biopsy data ((the presence or not of an infection with H. pylori, gastritis activity (graduated, depending on the degree of infiltration into neutrophils, in absent, mild, moderate or severe), gastric atrophy (absent or present), gastric intestinal metaplasia (absent or present)), weight and height and then we calculated the body mass index (BMI). 


\section{Statistical analysis}

The data were entered and analyzed using SPSS version 23 software. We calculated simple frequencies for the qualitative variables, the means and the standard deviations for the quantitative variables. Comparisons of percentages on paired series were made by McNemar's Chi-square test, and by Fisher's bilateral exact test in case of significance but invalidity of this test. The differences with a value of $p$ $<0.05$ were considered to be statistically significant.

\section{RESULTS}

\section{A. General characteristics of the population (Table 1)}

TABLE 1: GENERAL CHARACTERISTICS OF THE POPULATION

\begin{tabular}{|c|c|c|c|}
\hline & $\begin{array}{c}\text { General } \\
\text { population } \\
(\mathrm{n}=120)\end{array}$ & $\begin{array}{c}\text { Patients with } \\
\text { diabetes } \\
(\mathrm{n}=77)\end{array}$ & $\begin{array}{c}\text { Controls } \\
(\mathrm{n}=43)\end{array}$ \\
\hline Mean age (years) & $50 \pm 2.1$ & $55 \pm 2.12$ & $44 \pm 1.9$ \\
\hline Gender (\%(n)) & $\begin{array}{c}34.16 \\
(\mathrm{n}=41)\end{array}$ & $\begin{array}{c}38.96 \\
(\mathrm{n}=30)\end{array}$ & $\begin{array}{c}25.58 \\
(\mathrm{n}=11)\end{array}$ \\
\hline Sex ratio & 0.51 & 0.63 & 0.34 \\
\hline $\begin{array}{c}\text { Type of diabetes } \\
\text { (Type2/Type1) }(\%(\mathrm{n}))\end{array}$ & - & $88.31(68) /$ & - \\
\hline $\begin{array}{c}\text { Mean duration of } \\
\text { diabetes (years) }\end{array}$ & & $11.68(\mathrm{n}=9)$ & \\
\hline Mean HbA1C $(\%)$ & - & $9.3 \pm 2.1$ & - \\
\hline
\end{tabular}

\section{B. Endoscopic lesions}

The frequency of upper endoscopic lesions was $70.13 \%$ $(n=54)$ and $74.42 \%(n=32)$, respectively, for diabetics and non-diabetics ( $p$ value $=0,234)$ (Table 2$)$.

TABLE 2: PREVALENCE OF UPPER ENDOSCOPIC LESIONS IN DIABETICS AND CONTROLS

\begin{tabular}{|c|c|c|c|}
\hline Upper endoscopic lesions & Diabetics & Controls & p value \\
\hline Duodenal ulcer disease (\%) & $3,9(\mathrm{n}=3)$ & $2(4,65 \%)$ & 0,472 \\
\hline Esophagitis (\%) & $15,58(\mathrm{n}=12)$ & $5(11,63 \%)$ & 0,556 \\
\hline Hiatal hernia (\%) & $15,58(\mathrm{n}=12)$ & $3(6,98 \%)$ & 0,224 \\
\hline Ulcerative gastritis (\%) & $32,47(\mathrm{n}=25)$ & $11(25,58 \%)$ & 0,742 \\
\hline $\begin{array}{c}\text { Congestive and nodular } \\
\text { gastritis }(\%)\end{array}$ & $61(\mathrm{n}=47)$ & $27(62,79 \%)$ & 0,514 \\
\hline
\end{tabular}

\section{Histological lesions}

The prevalence of histological lesions was $67.5 \%(\mathrm{n}=$ $52)$ and $74.42 \%(n=32)$, respectively, for diabetics and non-diabetics $(\mathrm{p}=0.72)$. The prevalence of $\mathrm{H}$. pylori infection was $19.48 \%(\mathrm{n}=15)$ and $11.63 \%(\mathrm{n}=5)$, respectively, for diabetics and non-diabetics $(\mathrm{p}=0.27)$.

Histology found chronic gastritis, gastric atrophy and intestinal metaplasia in $61 \%, 3.9 \%$, and $2.6 \%$ of the cases, respectively (Table 3 ).

TABLE 3: PREVALENCE OF HISTOLOGICAL LESIONS IN DIABETICS AND CONTROLS

\begin{tabular}{|l|c|c|c|c|}
\hline \multicolumn{2}{|c|}{ Histological lesions } & $\begin{array}{c}\text { Patients with } \\
\text { diabetes }(n=120)\end{array}$ & $\begin{array}{c}\text { Controls } \\
(\mathrm{n}=77)\end{array}$ & $\begin{array}{c}\mathrm{p} \\
\text { value }\end{array}$ \\
\hline \multirow{2}{*}{$\begin{array}{l}\text { Gastritis } \\
\text { activity }\end{array}$} & Mild (\%) & $10.39(\mathrm{n}=8)$ & $16.28(\mathrm{n}=7)$ & 0.772 \\
\cline { 2 - 5 } & Moderate $(\%)$ & $5.19(\mathrm{n}=4)$ & $2.32(\mathrm{n}=1)$ & 0.345 \\
\cline { 2 - 5 } & Severe (\%) & $2.60(\mathrm{n}=2)$ & $2.32(\mathrm{n}=1)$ & 0.442 \\
\hline \multicolumn{2}{|c|}{ Gastric atrophy (\%) } & $3.9(\mathrm{n}=3)$ & $6.98(\mathrm{n}=3)$ & 0.745 \\
\hline \multicolumn{2}{|c|}{ Intestinal metaplasia (\%) } & $2.60(\mathrm{n}=2)$ & $4.65(\mathrm{n}=2)$ & 0.656 \\
\hline
\end{tabular}

\section{DISCUSSION}

The association between $\mathrm{H}$. Pylori infection and diabetes was first reported in 1989 by Simon L et al [2]. Since then, several studies have been carried out to better characterize this association. Several authors had joined the result of Simon $\mathrm{L}$ et al by showing an association between type 2 diabetes and H. Pylori infection [3], [4], [5]. Currently, this association remains debated.

In our study, endoscopic lesions were very common $(71.66 \%)$. They were more frequent in the controls but with no significant difference $(74.42 \%, 70.13 \%$, $p$ value $=0,234)$. Histological lesions were also more frequent in the controls with no significant difference $(74.42 \%, 67.5 \%$, p value $=0,72$ ).

H. Pylori infection was more frequent in diabetics compared to controls without reaching the significance set point $(19.48 \%, 11.63 \%$, p value $=0,27)$. Similarly, the prevalence of $\mathrm{H}$. Pylori infection was significantly more frequent in type 1 diabetes than in type 2 diabetes $(44.44 \%$ $(\mathrm{n}=4), 16.18 \%(\mathrm{n}=11)$, $\mathrm{p}$ value $=0.04)$.

Several studies have also shown no association between diabetes and $\mathrm{H}$. Pylori infection. Zhou $\mathrm{F}$ et al had conducted a control case study that enrolled 241 type 2 diabetics and 69 controls. The diagnosis of $\mathrm{H}$. Pylori infection was made by rapid urease test and the determination of anti-H. Pylori antibodies of the immunoglobulin $\mathrm{G}$ type. The authors have not shown an association between diabetes and infection to $\mathrm{H}$. Pylori but have shown an association of this infection and diabetic nephropathy [6]. Similarly, Sotuneh N et al had analyzed the association of H. Pylori infection with diabetes in 1300 subjects whose age was over 60 years. The prevalence of $\mathrm{H}$. Pylori infection in diabetics and non-diabetics was respectively $77.5 \%$ and $75.7 \%$ with no statistically significant difference ( $p$ value $=0.523)$ [7]. Likewise, Oluemy A et al had not shown any association too. The frequency of $\mathrm{H}$. Pylori infection was $18 \%$ in diabetics and $13 \%$ in non-diabetics ( $p$ value=0.52) [8]. Several authors around the world have shown the same result [9]-[13].

However, many studies report an association between diabetes and $\mathrm{H}$. Pylori infection. According to a metaanalysis published by Jun Zhen li et al, the prevalence of infection in diabetics was significantly more frequent compared to those without diabetes $(54.9 \%, 47.5 \%$, p value $<10^{-3}$, OR = 1.69). According to this same metaanalysis, in the group of diabetics, H. Pylori infection was more frequent in type 2 diabetes than in type 1 diabetes $(56.5 \%, 36.2 \%)$. The difference was not statistically significant between the type 1 diabetic group and the control group $(\mathrm{p}$ value $=0.38$, OR $[95 \% \mathrm{CI}]=1.23[0.77-$ 1.96]). In contrast, H. Pylori infection was more frequent in type 2 diabetics compared to the control group ( $\mathrm{p}<0.001$, OR $[95 \% \mathrm{CI}]=2.05[1.67-2.52])$. This association has mainly been linked to the insulin resistance which characterizes type 2 diabetes and which could be sustained by $H$. Pylori infection [14]. Kraue I et al analyzed the association of specific antibodies for $\mathrm{H}$. Pylori infection in type 1 diabetics, their family members, and in a control group. Antibodies specific for $\mathrm{H}$. Pylori infection were significantly lower in type 1 diabetics. This was explained by their young age. Moreover, the authors suggest a 
protective effect of H.Pylori infection against type 1 diabetes in subjects at risk. However, the number of type 1 diabetics was low, which limits the value of this result [15].

\section{CONCLUSION}

An association between diabetes and H. Pylori infection was not established in our study and remains debated in the scientific literature. Other studies are essential to better characterize this association.

\section{REFERENCES}

[1] World Gastroenterology Organisation. World Gastroenterology Organisation Global Guideline: Helicobacter pylori in developing countries. J Clin Gastroenterol. 2011;45(5):383-8.

[2] Simon L., Tornóczky J., Tóth M., Jámbor M., Sudár Z. The significance of Campylobacter pylori infection in gastroenterologic and diabetic practice. Orv Hetil. 1989;130(25):1325-9.

[3] Bajaj S., Rekwal L., Misra S. P., Misra V., Yadav R. K., Srivastava A. Association of helicobacter pylori infection with type 2 diabetes. Indian Journal of Endocrinology and Metabolism. 2014;18(5):694-9.

[4] Yang G. H., Wu J. S., Yang Y. C., Huang Y. H., Lu F. H., Chang C. J. Gastric Helicobacter pylori infection associated with risk of diabetes mellitus, but not prediabetes. J Gastroenterol Hepatol. 2014;29(10):1794-9.

[5] Zhou X., Zhang C., Wu J., Zhang G. Association between Helicobacter pylori infection and diabetes mellitus a metaanalysis of observational studies. Diabetes Res Clin Pract. 2013;99(2):200-8.

[6] Zhou $\mathrm{F}^{1}$, Zhong $\mathrm{X}^{2}$, Chen $\mathrm{J}^{3}$, Li $\mathrm{C}^{4}$, Shang $\mathrm{M}^{4}$, Jiang $\mathrm{C}^{4}$, and al Helicobacter pylori infection associated with type 2 diabetic nephropathy in patients with dyspeptic symptoms. Diabetes Res Clin Pract. 2015;110(3):328-34.

[7] Narges Sotuneh, ${ }^{1}$ Seyed Reza Hosseini, $, 2,3$ Javad ShokriShirvani, ${ }^{1}$ Ali $\quad$ Bijani, ${ }^{2}$ and Reza Ghadimi ${ }^{2,3}$. Helicobacter Pylori Infection and Metabolic Parameters: Is There an Association in Elderly Population?. Int J Prev Med. 2014;5(12):1537-42.

[8] Aderemi Oluyemi, Ebere Anomneze, Stella Smith, and Olufemi Fasanmade. Prevalence of a marker of active helicobacter pylori infection among patients with type 2 diabetes mellitus in Lagos, Nigeria. BMC Res Notes. 2012;5:284.

[9] Xia H-HX, Talley JN, Kam EPY, Young LJ, Hammer J, Horowitz M. Helicobacter pylori infection is not associated with diabetes mellitus nor with upper gastrointestinal symptoms in diabetes mellitus. Am J Gastroenterol. 2001;96:1039-46.

[10] Dore MP, Bilotta M, Malaty HM, Pacifico A, Maioli M, Graham DY. et al. Diabetes Mellitus and Helicobacter pylori infection. Nutrition. 2000;16(6):407-10.

[11] Woodward M, Morrison C, McColl K. An investigation into factors associated with Helicobacter pylori infection. J Clin Epidemiol. 2000;53:175-81.

[12] Demir M, Migneco A, Nista EC, Gasbarrini G, Gasbarrini A, Pitocco D. et al.Helicobacter pylori prevalence in Diabetes Mellitus patients with Dyspeptic Symptoms and Its Relationship to Glycemic Control and Late Complications. Dig Dis Sci. 2008;53:2646-9.

[13] Stanciu OG, Trifan A, Sfarti C, Cojocariu C, Stanciu C. Helicobacter pylori infection in patients with diabetes mellitus. Rev Med Chir Soc Nat Iasi. 2003;107(1):59-65.

[14] Jun-Zhen Li, Jie-Yao Li, Ting-Feng Wu, Ji-Hao Xu, Can-Ze Huang, Di Cheng, et al. Helicobacter pylori Infection Is Associated with Type 2 Diabetes, Not Type 1 Diabetes: An Updated MetaAnalysis. Gastroenterol Res Pract. 2017; 2017: 5715403.

[15] Krause $\mathrm{I}^{1}$, Anaya JM, Fraser A, Barzilai O, Ram M, Abad V et al. Anti-infectious antibodies and autoimmune-associated autoantibodies in patients with type I diabetes mellitus and their close family members. Ann N Y Acad Sci. 2009;1173:633-9. 